九州大学学術情報リポジトリ

Kyushu University Institutional Repository

Report on the ophiurans from off Ogasawara Islands and from off the Yaeyama group, Nippon

Murakami, Shiro

Amakusa Marine Biological Laboratory, Kyusyu Imperial University

https://doi.org/10.5109/22600

出版情報：九州大学大学院農学研究院紀要. 7 (7)，pp.235-257，1944-06. Kyushu Imperial University バージョン：

権利関係 : 
Journal of the Department of Agriculture, Kyūsyū Imperial University, Vol. 7, No. 7;

June 15,1944

\title{
REPORT ON THE OPHIURANS FROM OFF OGASAWARA ISLANDS AND FROM OFF THE YAÉYAMA GROUP, NIPPON ${ }^{1)}$
}

\author{
Shiro MURAKaMI
}

In 1943, in his investigations on the Ophiurans of the coral reefs of Isigaki-sima, Yaéyama, the author could recognize that the majority of them were referable to tropical elements. The Ophiurans of Ogasawara (Bonin) Islands, which have hitherto been dealt with very insufficiently, represented by only two littoral forms, namely, Ophiarachna incrassata (LAMARCK) and Ophiocoma scolopendrina (LAMARCK) (MATSUMoto, 1917), are also derivatives from tropical forms. I hoped to carry out further a research on the sublittoral faunae of these districts. The late Dr. Hayato IKEDA of the Fisheries Institute of Kyūsyū Imperial University made a good collection of Ophiurans on board of a coral-fishing boat off Ogasawara Islands and off the Yaéyama Group during his expeditions in 1940, and kindly placed them at my disposal for study. In addition to these, a number of Ophiuran specimens, probably obtained by him at one of the above mentioned localities, have been preserved, without label, at the Zoological Laboratory of the said University, and it seems to be suitable to treat them together in the present paper. In view of the fact that very little work has ever been done on the sublittoral Ophiurans of these districts, it must be of great interest to study such a valuable material, most of which belong to the forms rare and difficult to obtain. A close examination of them has revealed that the collection consists of twenty-two species, as will be described here in the

1) Contributions from the Zoological Laboratory, Kyūsyū Imperial University, No. 168; Papers from the Amakusa Marine Biological Laboratory, No. 90. 
following pages. The following species are contained in the collection, and among them eight are deemed to be new to science:

Order Phrynophiurida

Family Ophiomyxidae

1. Ophiomyxa australis LÜTKEN

2. Ophiobyrsa strictima sp. nov.

3. Ophiobrachion hamispinum sp. nov.

Family Trichasteridae

4. Astroceras calix sp. nov.

5. Astroceras coniunctum sp. nov.

6. Astroceras paucispinum sp. nov.

Family Asteroschematidae

7. Asteroschema yaéyamensis sp. nov.

Family Gorgonocephalidae

8. Asteroporpa hadracantha ClARK

9. Astrodendrum sagaminum (DöDERLEIN)

10. Astrocladus coniferus (DöDERLEIN)

11. Astroglymma sculptum (DöDERLEIN)

12. Astrothamnus bellator (KœHLER)

13. Astroclon propugnatoris LYMAN

Order Laemophiurida

Family Ophiacanthidae

14. Ophiomitrella ikedai sp. nov.

15. Ophiacantha bisquamata MATsumoto

16. Ophiacantha pentagona KGELER

17. Ophiocamax rugosa KcEHLER

Family Hemieuryalidae

18. Ophiomaris pentagona sp. nov.

Order Gnathophiurida

Family Ophiotrichidae

19. Ophiothrix vetusta KGELER

Order Chilophiurida

Family Ophiolepididae

20. Ophiomusium simplex LYMAN

Family Ophiodermatidae

21. Pectinura aequalis (LyMAN)

Family Ophiochitonidae

22. Ophioplax lamellosa Matsumoto 
Among these, Ophiacantha pentagona is an intertropical species, which is widely distributed in both the Indo-Pacific and Atlantic, but not in the Arctic or Antarctic. O. australis, A. sagaminum, A. coniferus, A. sculptum, A. propugnatoris, O. bisquamata, $O$. rugosa and $O$. simplex are Indo-Pacific in distribution, ranging from the Indian Ocean or Malaysian Waters to Nippon. A. bellator, $O$. vetusta and $P$. aequalis have been reported from the Malaysian Waters to Philippines, but not from Nippon. A. hadracantha and $O$. lamellosa have been recorded only from vicinities of Honsyū, and were regarded as representatives of the Honsyu species. Accordingly the greater part of sublittoral forms of the regions in question may also be regarded to represent tropical elements.

Here I must express my hearty thanks to Professor Dr. H. OHSHIMA for giving me kind guidance and suggestion during my study. Further, I wish also to thank the late Dr. H. IKEDA for the privilege which he gave me to undertake the work. The photographs are from the hands of $\mathrm{Mr}$. T. KaWAHARA of the Zoological Laboratory, Kyūsyū Imperial University.

\section{SYSTEMATICS}

Family Ophiomyxidae

\section{Ophiomyxa australis LÜTKEN}

Lütren, 1869, p. 45 \& 99. Clark, 1915, p. 168, pl. I, figs. 1-2. Matsumoto, 1917, p. 19, fig. 3, pl. I, figs, 4-7.

Localities.-Off Ogasawara, 1940; two specimens. Off Yaéyama, 1940; seven specimens.

Distribution.-Sagami Sea. Tyōsen Strait. Eastern Sea. Mauritius. Sulu Sea. Amboina. Caroline Islands. Southern Australia. Bass Strait. New Zealand. Fiji Islands. Tongatabu Is.

The specimens before me range from 8 to $18 \mathrm{~mm}$ across the disk. The oral papillae, free margin of which is neither strongly serrated nor transparent, are five in number on a side of an oral angle, among which distal two are rudimentary. The colour of dried specimens is brown on the disk and gray on the arms, the disk being not spotted with darker shades as it is said to be in MATSUMOTO's specimens. 


\section{Ophiobyrsa strictima sp. nov.1)}

(Text-figs. 1-2)

Disk $23 \mathrm{~mm}$ in diameter; arms broken, but more than $190 \mathrm{~mm}$ long in intact state; breadth of arm $3.5 \mathrm{~mm}$ at base.

Disk pentagonal, covered with a thick skin carrying numerous small compact scales, majority of which bear single spinelet.

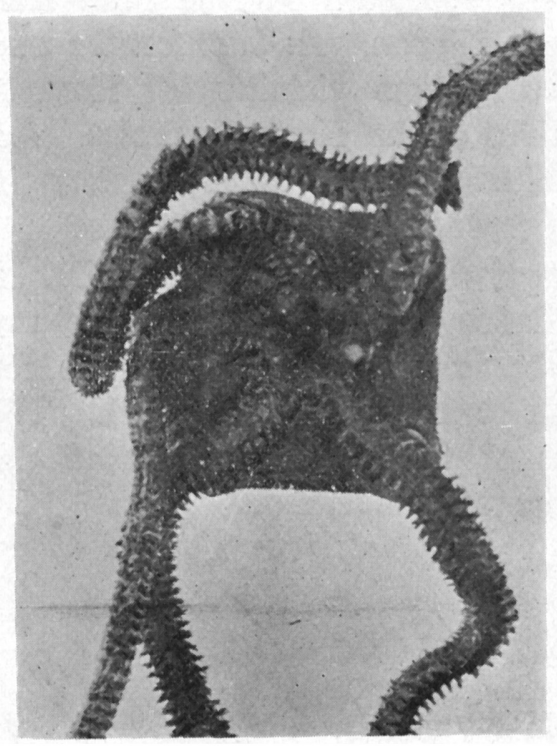

A

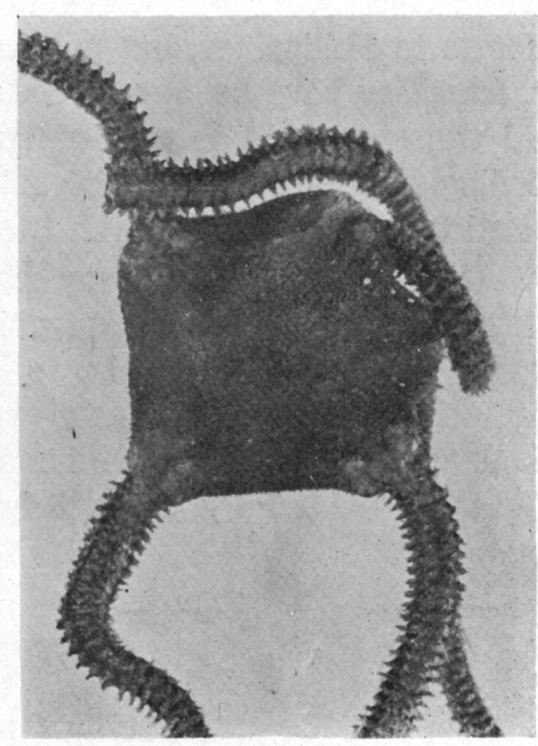

B

Fig. 1." Ophiobyrsa strictima.

A. From below. B. From above. Slightly enlarged.

Radial shields faintly indicated, small, broadly separated from each other, furnished with spinelets on the surface. Interbrachial spaces below also covered with similar covering to that of the dorsal side of disk. Genital slits large, reaching from the oral shield to the periphery of disk.

Oral shields small, oval, somewhat longer than broad. Adoral shields also of small size, triangular, longer than broad, slightly curved so as to embrace the oral shield, but not in contact with each other within. Oral plates stout. Oral papilla single, or sometimes absent, small, spiniform. Dental papillae numerous, arranged

1) Strictim, signifying closely, in reference to the disk closely covered with numerous small scales. 
in three more or less irregular vertical rows, terminating in two or three spinelets at the end.

Arms slender, uniformly tapering. Dorsal arm plates broken into fragments, each of which bears small, conical granules, but lateral ones are occasionally free from such granules. First ventral arm plates rather small, tetragonal, broader without than within. Following ones at first also tetragonal, with a distal border notched at the middle, broader than long, but becoming trapezoid distally, with lateral sides concave and diverging outwards. They are in contact with each other throughout the whole length of arm. Side arm plates narrow, broadly separated from each other both above and below. Arm spines seven in number near the disk, but reduced to five distally, less than a joint in length, flat, furnished with thorns along the margin; the lowest one is hook-shaped, having

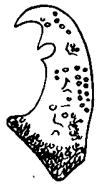

A

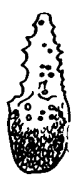

B

Fig. 2. Arm spines of Ophiobyrsa strictima.

A. Undermost one.

B. Upper one. $\times 28$. two to six branches along the proximal side, which increase in length towards the extremity. No tentacle scales.

Colour (dried from alcohol), brown.

One specimen; locality unknown.

The new species is closely related to O. acanthinobrachia CLARK in carrying a number of spinelets on the dorsal side of arm, but is easily distinguished from it by the compact disk scaling, by the oval oral and narrow adoral shields, and by the dental papillae arranged in three more or less irregular rows.

\section{Ophiobrachion hamispinum sp. nov. ${ }^{1}$}

(Text-figs. 3-4)

Disk $14 \mathrm{~mm}$ in diameter; arms $80 \mathrm{~mm}$ long. Breadth of arm about $2 \mathrm{~mm}$ at base. Disk flat, pentagonal, slightly concave at the interradial border, covered with a thick skin containing many small, rounded, more or less scattered scales, each of which bears a conical spinelet. Radial shields small, about one-third of disk radius in length, elongate, three times as long as broad, slightly enlarged distally, carrying a number of coarse granules or spinelets

1) Hamus, signifying hook, and spina, signifying spine, in reference to the hookshaped arm spines. 
at the proximal part. Interbrachial spaces below are like that of the dorsal side of disk. Genital slits large.

Mouth parts and arms also covered with a thick skin. Oral shields very small, somewhat triangular, with angles rounded, broader than long. Adoral shields large, oblong, about two times

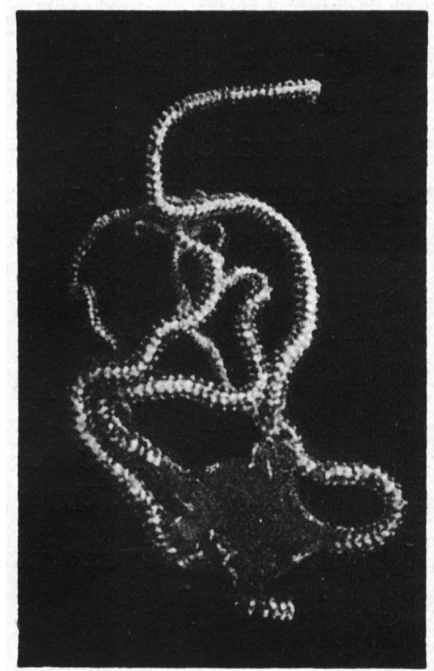

A

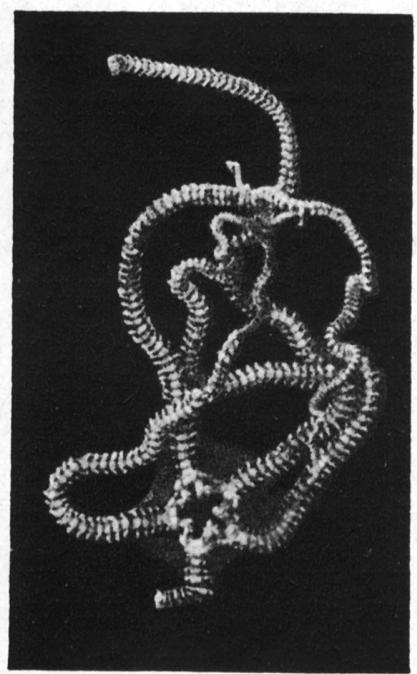

B

Fig. 3. Ophiobrachion hamispinum.

A. From above. B. From below. About natural size.

as long as broad, with proximal and distal ends rounded, longer borders nearly parallel; they are not meeting within and separate the first side arm plate from the oral shield distally. Oral plates very conspicuous, higher than broad. Oral papillae one or two on a side, sharply pointed; distal one larger than the proximal one. Dental papillae numerous, crowded at the tip of jaw, long and acute, distal half of which is transparent.

Arms slender, slowly tapering. Dorsal arm plates small, rudimentary, broken into two pieces laterally by longitudinal interval, each of which is elliptical and longer than broad. First ventral arm plates very large, as large as, or somewhat larger than, the following ones, much broader than long, proximal margin rounded, distal one somewhat trilobed. Second one pentagonal, with a very wide proximal angle, much broader than long. Following several plates truncated at the proximal angle so as to become hexagonal 
in shape, also broader than long, the distal border much longer than the proximal one; but distally they become tetragonal and as long as broad. First two or three ventral arm plates are in çontact with each other, but soon becoming separated from each other distally by a narrow interval. Side arm plates not meeting both above and below, bearing five conspicuous mamelons along the distal ridge, each of which supports an arm spine. Arm spines five in number, transparent, hookshaped, strongly curved inwardly at the terminal part, carrying two or three branches along the proximal side, which increase in length as it

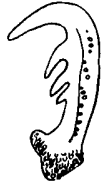

Fig. 4. Arm spine of Ophiobrachion hami. spinum. $\times 28$. proceeds distally. Tentacle pores inconspicuous, without scales.

Colour (dried from alcohol), brown.

Locality.-Off Yaéyama, 1940; three specimens.

As only a single Ophiuran, $O$. uncinatus, described by LYMAN has been known in the present genus, it is my great joy to find such a rare form in the collection. The number and shape of arm spines well serve to distinguish $O$. hamispinum from $O$. uncinatus. The specimens at hand range from 7 to $16 \mathrm{~mm}$ in the diameter of disk, showing a little variation in their characters.

\section{Family Trichasteridae}

\section{Astroceras calix sp. nov. ${ }^{1}$}

(Text-figs. 5-6)

Disk $5 \mathrm{~mm}$ in diameter; arms about $40 \mathrm{~mm}$ long. Breadth of arm $2 \mathrm{~mm}$ at base.

Disk five-lobed, concave at the interradial border, thick and flat, covered with a thick skin containing a number of thin scales. Radial shields very large, nearly reaching the centre of disk, where they are flattened and are in contact with each other, somewhat narrow and swollen at the distal part, furnished with coarse granules on the surface; at the distal end of each radial shield is a conspicuous cup-shaped spine, which is exceedingly enlarged and thorny at the tip. Genital slits small, nearly vertical.

1) Calix, signifying $c u p$, in reference to the conspicuous cup-shaped spines of radial shield and proximal part of arm. 
The mouth parts are faintly indicated by the skin. Oral shields small, triangular. Adoral shields large, trapezoid, broader within than without, fully in contact with each other at the interradial

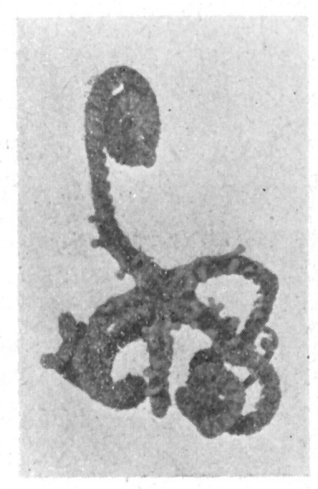

A

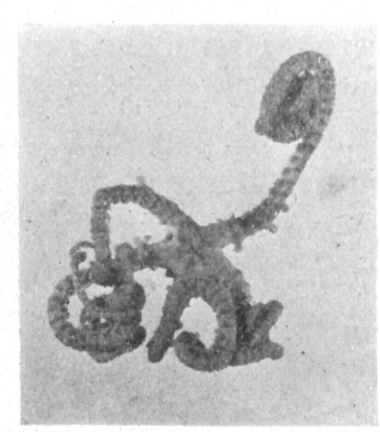

B

Fig. 5. Astroceras calix.
A. From above.
B. From below.

Slightly enlarged.

area. Teeth about six in number on a jaw, thick and stout, triangular in shape, with a rounded proximal angle, broader than long; the one ventrally situated is a little the smallest. Oral papillae wanting, but papilla-like granules present along the oral slit.

Arms flat and naked on the dorsal side at base, but becoming rounded and remarkably granulated distally. Lateral bars con-

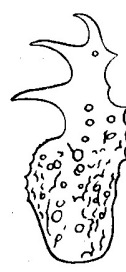

A

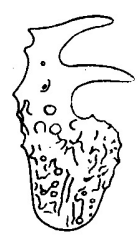

B

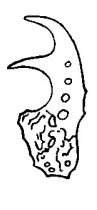

C spicuous at the proximal four or five joints, and well separated from each other above, each of which bears one or rarely two conspicuous spines at the upper end similar to those of the radial shield. Ventral arm plates small, tetragonal. Side arm plates small, reduced to a spine-bearing shaft, broadly separated from each other. Arm spines two in number to each side arm plate, blunt and calix. $\times 80$.

Fig. 6. Transform entacle pores without spines. Hook thorny at the tip. First tentacle pores without
spines have no regular series of holes in the lamina.

Colour (dried from alcohol), brown. 
Locality.-Off Yaéyama, 1940; two specimens.

Astroceras calix is obviously allied to A.pergamena LYMAN and A. pergamena var. granulatum MoRTENSEN, but the conspicuous cup-shaped spines born on the radial shields and on the dorsal side of arm at base are a distinct character to keep it separate from the latter species. Further, the granulation of arms and radial shields, in combination with the larger radial shields, forms another feature to characterize the new species.

\section{Astroceras coniunctum sp. nov. ${ }^{1)}$}

(Text-figs. 7-8)

Disk $9 \mathrm{~mm}$ in diameter; arms more than $70 \mathrm{~mm}$ long. Breadth of $\operatorname{arm} 2 \mathrm{~mm}$ at base.

Disk and arms covered with a thick skin carrying small, delicate scales. Disk thick, five-lobed, slightly notched at the interradial border. Radial shields very large, much longer than broad, in contact with each other at the centre of disk, each one of which is provided with a linear series of three or four rounded, thorny spines on the surface. Genital slits small, oblique.

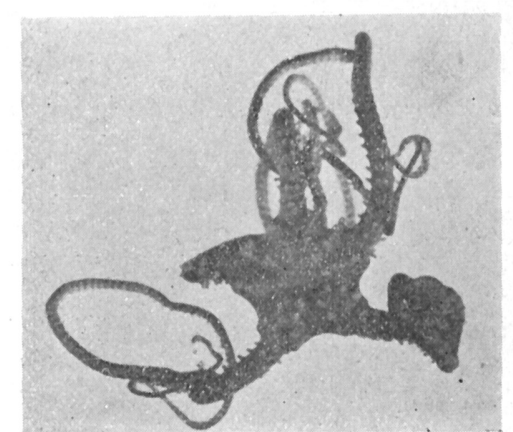

A

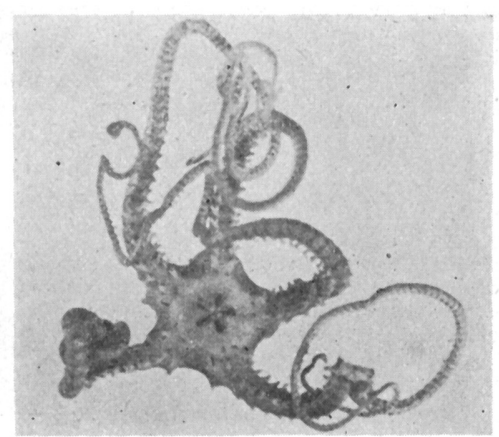

B

Fig. 7. Astroceras coniunctum.

A. From above. B. From below. Slightly enlarged.

Oral shields indistinct. Adoral shields large, situated almost horizontally, broader within than without, fully in contact with each other on the interradial line. Teeth stout, flat, longer than broad, somewhat triangular in shape, blunt at the proximal end;

1) Coniunctus, signifying adjoining, in reference to the spines, which are borne on the dorsal side of arm at base, approaching each other. 
the undermost one is the smallest and narrow. Oral papillae absent.

Arms rather slender, somewhat higher than broad at base. Lateral bars present at base of arm, small, in contact with each other on the dorsal side of arm; at the upper end of each lateral bar is a distinct, rounded, thorny spine, which

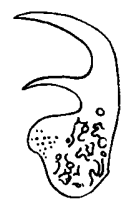

Fig. 8. Hook spine of Astroceras coniunctum. $\times 80$. stands side by side with a fellow of the opposite one. It is reduced in size as it goes distally, finally disappearing from the seventh or eighth joint. Ventral arm plates indistinct. Side arm plates small, broadly separated. Arm spines two in number, somewhat elongate, rough at the end. First tentacle pores unprotected. Hook spines are of the typical form and show the regular series of holes in the lamina.

Colour (dried from alcohol), deep brown above, but much lighter on the ventral side.

Locality.-Off Ogasawara, 1940; one specimen.

Only a single specimen is before me, but its characters are remarkable enough to make it a distinct species. It is another member closely related to $A$. pergamena LYMAN, but is easily distinguished from it by the fact that the lateral bars are in contact with each other on the dorsal side of arm, and the radial shield is furnished with a linear series of three or four spines on the surface.

\section{Astroceras paucispinum sp. nov. ${ }^{1}$}

(Text-figs. 9-10)

Disk $5 \mathrm{~mm}$ in diameter; arms all broken off at different distances from the disk, but the longest available being about $24 \mathrm{~mm}$ long. Breadth of arm $2 \mathrm{~mm}$ at base.

Disk flat, five-lobed, concave at the interradial border, covered with a thin integument containing a small number of thin scales. Radial shields small, about three-fifths of disk radius in length, less than three times as long as broad, separated from each other, rather irregular in shape, some ones of which are somewhat fusi-

1) Pauci, signifying few, and spina, signifying spine, in reference to a small number of spines borne on the dorsal side of arm at base. 
form, while the others are divided into two lobes at the proximal end; in the specimen at hand they are not furnished with spines or granules on the surface, but in life, some of them must have carried some such, for they show an articular process on the surface. Genital slits small, vertical.

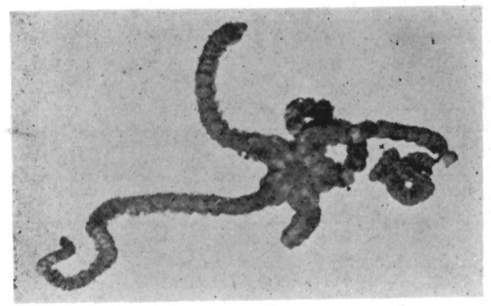

A

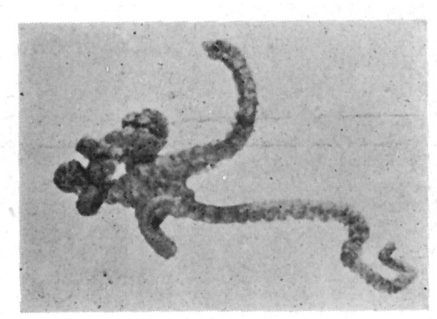

B

Fig. 9. Astroceras paucispinum.

A. From above. B. From below. Slightly enlarged.

Oral shields indistinct. Adoral shields large, enlarged and rounded at the distal part, narrow within, fully in contact with each other at the interradial area. Oral plates higher than broad. Teeth distinct, somewhat triangular in shape, with a rounded free margin, nearly as broad as long.

The dorsal side of arm flat at base, but becoming rounded and distinctly granulated distally. Lateral bars inconspicuous even at the base of arm, only a small number of which carry a small, rounded, rough spine at the upper end. Ventral arm plates small, quadrangular, broader than long. Side arm plates broadly separated from each other, reduced to a spine-bearing shaft. Arm spines two in number, small, some of which are blunt at the tip, while the others are tapering to a

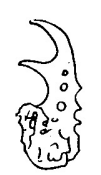

Fig. 10. Hook spine of Astroceras paucispinum. $\times 80$.

point. First tentacle pores without such spines. Hook spines show no regular series of holes in the lamina.

Colour (dried from alcohol), yellowish white.

Locality.-Off Ogasawara, 1940; one specimen.

The present specimen is not in good state of preservation, but as the features are very characteristic, it seems to be best to let it stand as a new species. This species somewhat resembles $A$. 
mammosum KøHLER, but the peculiar shape of radial shields, combined with the presence of granules on the dorsal side of arm, makes it separate from $A$. mammosum.

\section{Family Asteroschematidae}

\section{Asteroschema yaéyamensis sp. nov.}

(Text-fig. 11)

Disk $7 \mathrm{~mm}$ in diameter; arms cannot be accurately measured owing to their convolution, but roughly $150 \mathrm{~mm}$ long; the swollen basal part of arm $5 \mathrm{~mm}$ in breadth and $3 \mathrm{~mm}$ in height, but beyond it becoming $2.5 \mathrm{~mm}$ wide and $2 \mathrm{~mm}$ high.

Disk flat, about as high as the base of arm, pentagonal, distinctly notched at the interradial border, covered with numerous

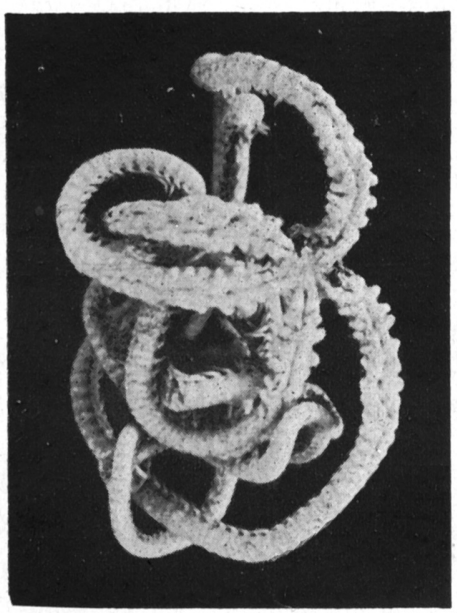

Fig. 11. Asteroschema yaéyamensis; from above. Slightly enlarged. compact, coarse, conical granules. Radial ribs small, about one half of radius in length, twice as long as broad, slightly enlarged distally, also provided with conical granules, separated from each other by a groove. Interbrachial spaces below and the mouth parts also covered with rather rounded granules; those of the latter are somewhat coarser than the rest. Genital slits small, nearly vertical.

Oral shields invisible. Adoral shields more or less bare in the preserved specimen, large, oblong, more than twice as long as broad, broadly in contact with each other on the interradial line. On each side of jaw are several distinct granules, corresponding to oral papillae. Teeth ten in number, large, stout, flat, rounded triangular in shape. Infradental papillae two in number, lying side by side, each of which is about one half of the following tooth in size, and triangular or rhomboidal in shape.

Arms also covered with rather regularly spaced, conical granules, swollen and ribbed laterally at the first seven or eight joints; beyond them becoming rounded, even, and slowly tapering. A 
shallow groove runs longitudinally along the dorsal side of arm at base. Arm spines long, cylindrical, rough at the tip. First tentacle pores without such spines; next one or four with one, and the rest with two spines; the inner one larger than the abradial one.

Colour (dried from alcohol), dirty gray.

Locality.-Off Yaéyama, 1940; one specimen.

The new species is very near to A. tumidum LYMAN, but is easily distinguished from it by smaller radial ribs, and by more numerous and more conspicuous arm ribs.

\section{Family Gorgonocephalidae \\ 8. Asteroporpa hadracantha $\mathrm{CLARK}$}

CLARK, 1911, p. 280, fig. 142.-1915, p. 182. Marsumoto, 1917, p. 67, fig. 17:

Localities.-Off Ogasawara, 1940; one specimen. Off Yaéyama, 1940; one specimen. Five specimens; locality unknown.

Distribution.-Sagami Sea. Off Omae Zaki Light. Ensyū Sea. Ōsumi. Eastern Sea.

\section{Astrodendrum sagaminum (DöDERLEIN)}

Gorgonocephalus sagaminus : DöDERLEIN, 1902, p. 321.

Astrodendrum sagaminum : DöDERLEIN, 1911, p. 38, pl. II, figs. 3-5, pl. VII, fig. 8. ClaRk, 1915, p. 185. Матsumoto, 1917, p. 73, fig. 21.

One specimen; locality unknown.

Distribution.-Sagami Sea. Ōsé Zaki, Suruga Gulf. Eastern Sea. Sea of Nippon. Indian Ocean.

\section{Astrocladus coniferus (DöDERLEIN)}

Astrophyton pardalis : DöDERLEIN, 1902, p. 323.

Astrophyton coniferum: DöberLeIN, ditto, p. 325.

Astrocladus dofleini : DöDerLeIN, 1910, p. 256.1)

Astrocladus coniferus : DöDERLEIN, 1911 , p. 46 \& 75, pl. II, figs. 7-7a, pl. IV, figs. 1-3a, pl. VII, figs. 5-6a \& 16. Clark, 1915, p. 186. Matsumoto, 1917, p. 77, fig. 23.

Localities.-Off Ogasawara, 1940; one specimen. Off Yaéyama, 1940; one specimen. Four specimens; locality unknown.

Distribution.-Misaki. Sagami Sea. Suruga Gulf. Off Omae Zaki Light. Ensyū Sea. Kagosima. Colnett Strait. Eastern Sea. Tyōsen Strait. Fusan. Wladiwostok. Indian Ocean.

1) "Schultze-Zool. Ergebn., IV", not accessible to me. 
The specimens before me measure from 12 to $50 \mathrm{~mm}$ across the disk. They are beset with many hemispherical tubercles on the dorsal side of disk and arms. Each radial rib carries a very conspicuous tubercle at the distal end. The ground colour of three specimens is dirty white, variegated with brownish purple, while the others are purplish black or gray.

\section{Astroglymma sculptum (DöDERLEIN)}

Astrophyton sculptum: DöDERLEIN, 1896, p. 299, pl. XVIII, fig. 29.

Astrodactylus sculptus: DoderLern, 1911, p. 56, fig. 13, a-b.

Astroglymma sculptum: DóderlerN, 1927, p. 47 \& 96, pl. I, figs. 3-4, pl. V, fig. 13.1) MorTensen, 1934, p. 5, pl. VI.

Three specimens; locality unknown.

Distribution.-Hong Kong. Amboina. Kei Islands.

\section{Astrothamnus bellator (KCEHLER)}

Astrotoma bellator: KєнцеR, 1904, p. 154, pl. XIX, fig. 8, pl. XXIII, fig. 1, pl. XXVIII, figs. 8-9.

Astrothamnus bellator: Матsumoтo, 1915, p. 60.

Locality.-Off Yaéyama, 1940; one specimen.

Distribution.-Off Sulu Archipelago.

The specimen at hand is about $10 \mathrm{~mm}$ in the disk diameter. The arm spines are six in number at three basal arm joints and then fall to five distally; in the type they are five from the first proximal. The other features show no distinct diversity from the type.

\section{Astroclon propugnatoris LYMAN}

Lyman, 1879, p. 69, pl. XVIII, figs. 481-486. Mortensen, 1933, p, 33, fig. 25, pl. II, fig. 3.

Three specimens; locality unknown.

Distribution.-Off Gotō Islands. Off Kei Islands.

Our specimens measure from 24 to $52 \mathrm{~mm}$ in the diameter of disk, but the arms are broken into fragments. Besides to mention that the features agree well with the type described by LYMAN, it is unnecessary to add any further account.

1) "Abh. Bayer. Akad. Wiss., XXXI, 6", not accessible to me. 


\section{Family Ophiacanthidae}

14. Ophiomitrella ikedai sp. nov.

(Text-fig. 12)

Disk $5.5 \mathrm{~mm}$ in diameter; arms torn away, but probably more than five times as long as the disk diameter in the intact state.

Disk rounded or somewhat decagonal, slightly notched at the interradial border, covered with a coating of many small, delicate scales, bearing a number of rather coarse, rough, rounded, scattered granules. Radial shields bare, rather of small size, less than one half of disk radius in length, triangular, somewhat longer than broad, separated from each other. Interbrachial spaces below very

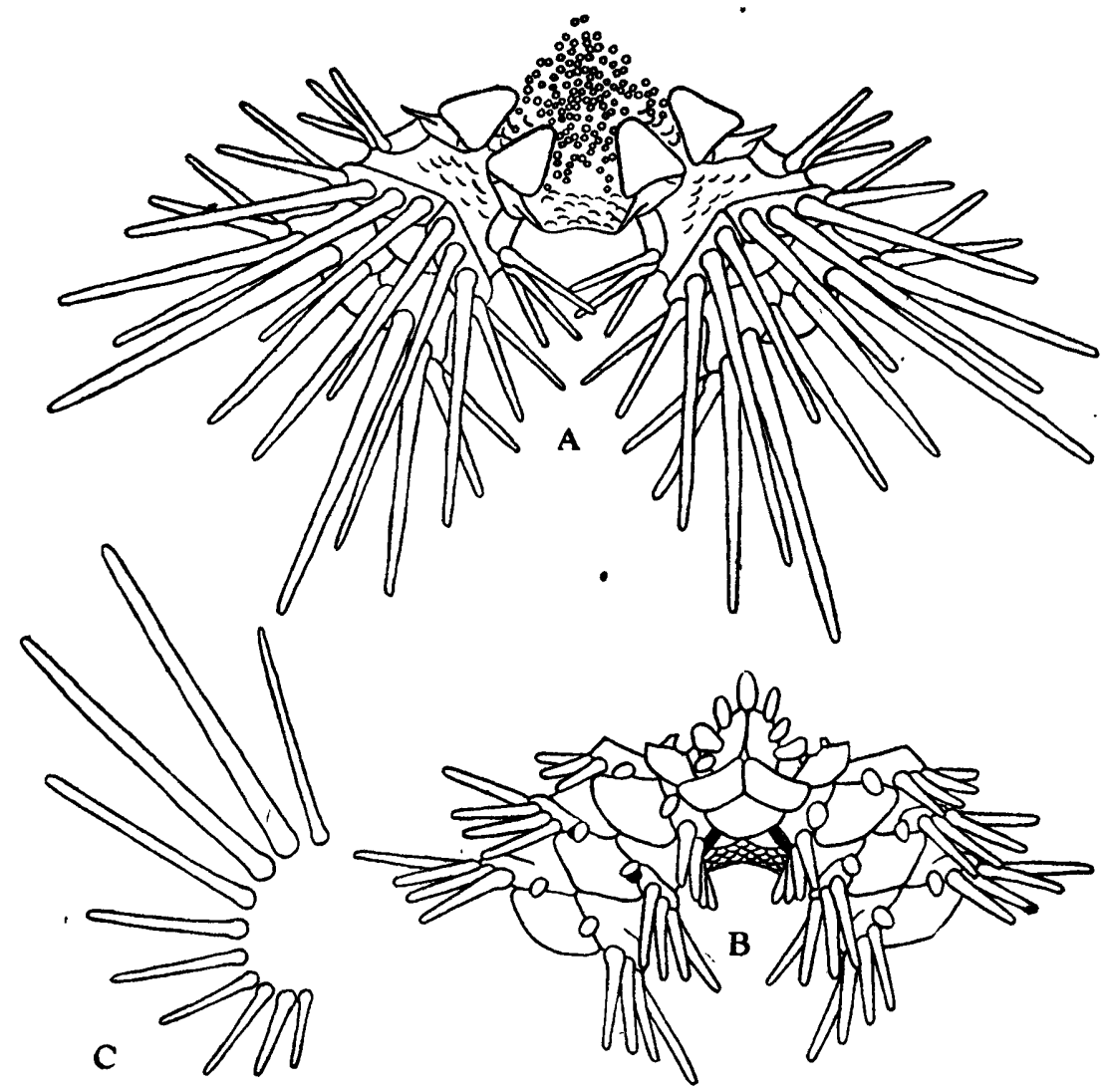

Fig. 12. Ophiomitrella ikedai.
A. From above.
B. From below.
C. Arm spines of one side of an arm joint near disk. $\times 11$. 
narrow, covered with a number of small, thin, imbricating scales, which are free from granules. Genital slits conspicuous.

Oral shields moderate, rhomboidal, much broader than long, with a distal angle rounded. Adoral shields large, trapezoid, broader within than without, about two times as long as broad, fully in contact with each other on the interradial line. Oral plates distinct, higher than broad. Oral papillae three or four on a side of an oral angle; the proximal one is elongate conical, while the distal ones are flat and enlarged at the end. Teeth somewhat triangular in shape, longer than broad, flat, blunt at the tip, but the one ventrally situated is conical.

Artms rather stout. Dorsal arm plates small, triangular, with a sharp proximal angle and a convex distal margin, broader than long, completely separated from each other by the side arm plate. First ventral arm plates small, somewhat hexagonal, broader than long. Following ones rhomboidal, with a distal angle rounded, much wider than long. Some proximal ventral arm plates are scarcely in contact, but beyond them becoming separated from each other as it approaches the tip. Side arm plates well developed, very prominent, meeting both above and below. Arm spines ten in number near the disk, falling to five distally, long and crowded, finely thorny on the surface; the uppermost one or the next is the largest, and about four times as long as an arm joint; the rest are reduced in length downwards, towards the undermost one which is the smallest, being about as long as a joint. Those of each side of the basal joints are continuous on the dorsal midline. Tentacle scales single for each pore, elongate; those of proximal two or three joints are spatulate, but becoming bluntly pointed as it proceeds distally.

Colour (dried from alcohol), grayish white.

Locality.-Off Yaéyama, 1940; ten specimens.

The specimens at hand range from 3.5 to $5.5 \mathrm{~mm}$ in the disk diameter. $O$. ikedai is nearly allied to $O$. mutata KcHLER, $O$. sagittata K৫HLER and $O$. subjecta KœHLER, but is easily distinguished from them by the spherical granules of disk, and by the rhomboidal oral and trapezoid adoral shields. The new species is dedicated in memory of the lamentable death of Dr. H. IKEDA, a talented echinologist of our country. 


\section{Ophiacantha bisquamata MATSUMOTO}

Ophiacantha bisquamata: Maтsuмото, 1915, p. 62.-1917, p. 120, fig. 31.

Ophiotreta bisquamata: KЁLЕR, 1930, p. 64.

Locality.-Off Yaéyama, 1940; six specimens.

Distribution.-Sagami Sea. Kei Islands.

The largest specimen before me is about $7.5 \mathrm{~mm}$ across the disk, but its arms are torn away at different distances from the disk. The larger ones are somewhat different from the type. 'The arm spines are more than those of the latter in number, being seven or eight near the disk, and the ventral arm plates are wider than long at least near the disk, while they are as long as wide in the type. But such differences seem to me to be hardly of specific value, being most probably due to the advanced age of the animals. The smaller ones agree well with the type even in minor features.

\section{Ophiacantha pentagona KGHLER}

K๕̈LeR, 1897, p. 342, pl. VIII, figs. 56-57. CLARK, 1915, p. 204 . Matsumoto, 1917, p. 116.

Locality.-Off Yaéyama, 1940; five specimens.

Distribution.-Uraga Channel. Sagami Sea. Suruga Gulf. Off Ōsima. Ensyū Sea. Kumano Sea. Tyōsen Strait. Southwest of the Gotō Islands. Eastern Sea. Malaysian Waters. West of Africa.

The present species is one of the common Ophiurans found in the Nipponese waters. I was also able to find it in the Sagami Sea and Suruga Gulf during my stay at the Mitsui Institute of Marine Biology.

\section{Ophiocamax rugosa K৫HLER}

Ophiocamax rugosa: K৫HLER, 1904, p. 139, pl. XXVI, figs. 4-7. C C LARK, 1915, p. 214. KєнLER, 1922, p. 147, pl. XXVII, figs. 5-8, pl. XXVIII, figs. 1-6, pl. XXIX, figs. 1-6, pl. XCIV, fig. 8.

Ophiocamax polyploca: $\mathrm{C}_{\mathrm{LARK}}, 1911$, p. 193, fig. 90.-1915, p. 214.

Locality.-Off Yaéyama, 1940; three specimens.

Distribution.-Eastern Sea. Off Kagosima Gulf. Philippine Islands. Off Zamboanga. Off southwest end of Timor. Kei Islands.

KGEHLER, who studied a vast number of specimens of this species collected by "Albatross" and found much variation among 
them, united Clark's O. polyploca with the present species. A close examination of the speciemens at hand has convinced me that they shall also be contained in the same category without fail. The largest specimen measures about $8 \mathrm{~mm}$ across the disk. The disk is rounded, slightly concave at the interradial border, and covered with coarse scales, each of which bears a thorny stump or spine. The radial shields are bare, large, triangular, longer than broad, and fully in contact with each other. Interbrachial spaces below are narrow, and are also covered with coarse scales bearing a thorny stump.

The oral shields are small, rhomboidal, producing a distal lobe, and thorny at the distal part. The adoral shields are very large, somewhat trapezoid in shape, broader within than without, closely appressed to each other, as well as to the oral shield, and furnished with one or two stumps on the surface. The oral plates are inconspicuous. The oral papillae are seven or eight in number on a side and elongate; the outer ones are crowded, and slightly enlarged and rough at the end, while the inner ones are conical. The teeth are also elongate.

The arms are broken, but rather stout. The dorsal arm plates are triangular or rhomboidal, broader than long, thorny at the distal part, and not in contact with each other. The ventral arm plates are large, rhomboidal, much broader than long, and separated from each other. At first they are smooth, but becoming rough by the spinules localized at the aboral part. The side arm plates are well developed, meeting above and below, and very prominent along the distal ridge which supports the arm spines. The arm spines are eight or nine in number near the disk and strongly serrated; the upper ones are very long, almost about three times as long as a joint, but they become smaller ventrad, the undermost one being, the smallest and less than a joint in length. The tentacle scales small and very thorny; there are three such scales to each proximal pore, but reduced to one distally. The colour of the specimen dried from alcohol is dirty white.

Family Hemieuryalidae

18. Ophiomaris pentagona sp. nov.

(Text-fig. 13) 
Disk $14 \mathrm{~mm}$ in diameter; arms about $10 \mathrm{~mm}$ long; breadth of arm $1.5 \mathrm{~mm}$ at base.

Disk somewhat decagonal, notched at the interradial border, elevated along the radial line; but sunken at the interradial area.. It is covered with twenty-one large plates, between which a number of small scales are intervening;, Central plate of moderate size, pentagonal, Radial plates also pentagonal, with an angle turning proximad. These plates are larger than the former, separated. from each other, as well as from the central plate, by elongate or oval scales. 'Radial shields very large, triangular, with a rounded abradial angle. They are separated from each other within by two large plates, one of which is the radial plate, while the other is a triangular plate just distal to the former. A number of distinct conical granules are borne on the margin of radial and its abcentral plates, and between the radial shields. Genital slits very indistinct.

Oral shields rhomboidal when viewed from

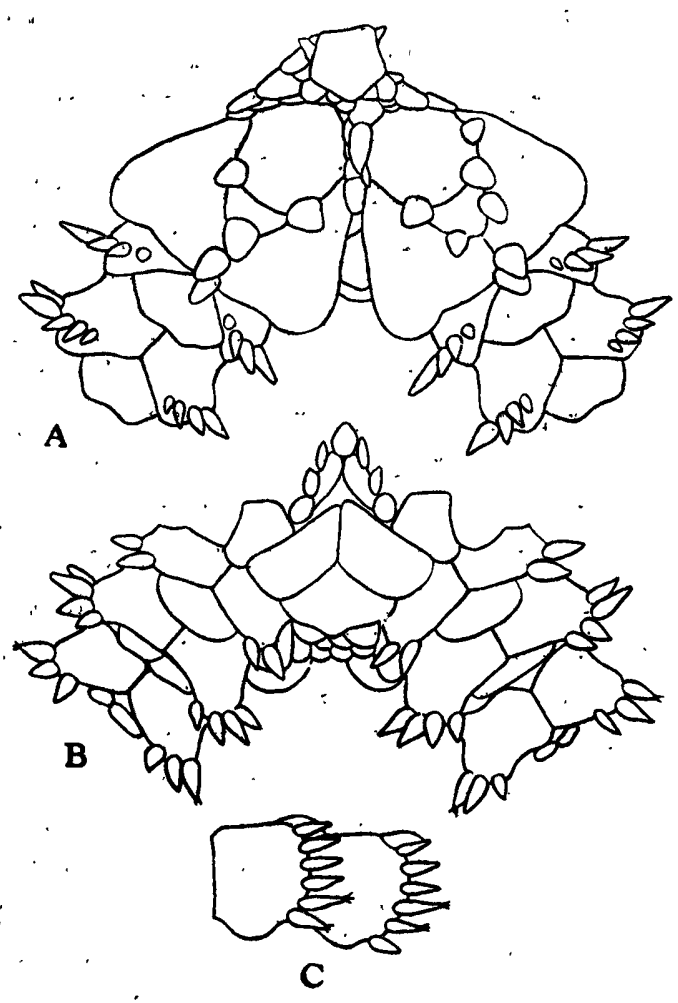

Fig. 13. Ophiomaris pentagona.

A. From above. B. From below.

C. Side view of two arm joints near disk. $\times 15$.

below, but in reality the distal angle protrudes upwards as a tonguelike lobe. Adoral shields very large, somewhat semicircular in shape, proximal border straight, distal one rounded, fully in contact with each other on the interradial line. Oral plates small, high. Oral papillae three or four on a side of an oral angle; the outermost one is broad and rounded along the free margin, -while the inner ones are narrow and pointed at the end. Teeth five in number 
on a jaw, of which the undermost one is pentagonal, longer than broad, and blunt at the tip, while the others are flat and spatulate.

Arms knobbed, stout at the base, gradually tapering distally, coiled vertically. Dorsal arm plates rather small, somewhat pentagonal, with an obtuse proximal angle, distal margin slightly notched at the middle, broader than long; they are well separated from each other by the side arm plate. First ventral arm plates moderate, pentagonal, with a proximal angle, much longer than wide, broader within than without. Second one nearly as large as the former, much broader than long, with a broad proximal angle and a convex distal margin. Following ones reduced in size abruptly and broken into fragments; finally becoming rudimentary. Side arm plates well developed, prominent along the distal edge, broadly in contact with each other both above and below. Arm spines six or seven in number, but falling to four distally. They are less than one half of a joint in length; upper ones somewhat slender, while the under ones robust. Two or three arm spines from below are thorny at the tip. Tentacle scales wanting.

Colour (dried from alcohol), white.

Locality.-Off Ogasawara, 1940; three specimens.

The new species is very near to $O$. projecta Matsumoto, especially in having granules on the dorsal side of disk, but differs from it in the scaling of disk. In $O$. projecta, the radial shields are separated from each other at the proximal part by one radial plate, but in $O$. pentagona, another large plate is intervening between the radial plate and radial shields. Further, the dorsocentral plate of the former is circular, while it is pentagonal in the latter; the species is named after the shape of that plate.

\section{Family Ophiotrichidae}

19. Ophiothrix vetusta K(EHLER

(Text-fig. 14)

KøHLER, 1930, p. 177, pl. X, figs. 5-7.

Localities.-Off Ogasawara, 1940; one specimen. Off Yaéyama, 1940; three specimens.

Distribution.-Kei Islands. 
The present specimens measure from 9 to $14 \mathrm{~mm}$ across the disk. The radial shields are comparatively longer than those of the type, but the other characters agree well with those of the latter.

Fig. 14. Ophiothrix vetusta; from above. $\times 1.5$.

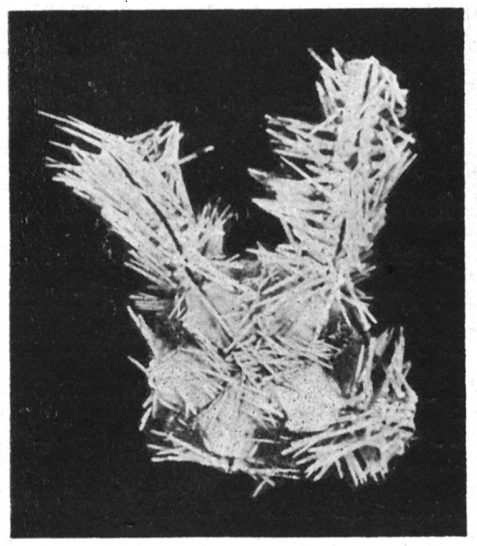

Family Ophiolepididae

\section{Ophiomusium simplex LyMAN}

Ophiomusium simplex: Lyman, 1878, p. 115, pl. I, figs. 10-11. Clark, 1915, p. 333. K๕ELER, 1922, p. 417, pl. LXXXVIII, figs. 10-11.

Ophiomusium sanctum: KøHLER, 1904, p. 59, pl. XI, figs. 7-9.

Locality.-Off Ogasawara, 1940; four specimens.

Distribution.-Eastern Sea. Southwest of the Goto Islands. Malaysian Waters. Amboina. Kei Islands.

Our specimens are almost of uniform size, measuring about $13 \mathrm{~mm}$ across the disk. The arrangement of disk plates in two specimens is like that of the simplex-type, while in the other two it is similar to that of the sanctum-type. But the arrangement of plates on the ventral side of disk is in accord with that of the simplex-type in all the specimens.

\section{Family Ophiodermatidae}

\section{Pectinura aequalis (LyMAN)}

Ophiopeza aequalis: LYMAN, 1882, p. 12, pl. XXVII, figs. 7-9.

Pectinura aequalis: CLARK, 1909b, p. 118.-1915, p. 303 . KœHLER, 1922, p. 337, pl. LXXVII, figs. 16-17. 
Locality.-Off Yaéyama, 1940; two specimens.

Distribution.-Philippine Islands. Kei Islands. New Guinea.

\author{
Family Ophiochitonidae
}

\title{
22. Ophioplax lamellosa Matsumoto
}

Matsumoto, 1915, p. 88.-1917, p. 330, fig. 92, pl. VI, fig. 9.

Locality.-Off Ogasawara, 1940; one specimen.

Distribution.-Off Kōzu-sima, Sagami Sea.

The present species has been known only by a single specimen, and it is worthy of special notice that we have the second specimen of this rare species in the collection. As the specimen at hand is well in accord with MATSUMOTo's original description and figures, any further comment of this species appears to be unnecessary.

\section{(Amakusa Marine Biological Laboratory, Kumamoto-ken)}

\section{LITERATURE}

Brock, J. 1888 Die Ophiuridenfauna des indischen Archipels. Zeitschr. wiss. Zool., XLVII, 3, pp. 465-539.

$\mathrm{C}_{\mathrm{LARK}}, \mathrm{H}$. L. 1909a Echinodermata, in scientific results of the trawling expedition of H. M. C. S. Thetis. Mem. Aust. Mus., IV, pp. 519-564, pls. XLVII-LVIII.

— 1909b Notes on some Australian and Indo-Pacific Echinoderms. Bull. Mus. Comp. Zoöl., LII, 7, pp. 109-135, pl. I.

1911 North Pacific Ophiurans in the collection of the United States National Museum. U. S. Nat. Mus., Bull. 75, pp. 1-302.

1915 Catalogue of recent Ophiurans: based on the collection of Museum of Comparative Zoölogy. Mem. Mus. Comp. Zoöl., XXV, 4, pp. 163-376, pls. I-XX.

Döderlein, L. 1896 Bericht über die von Herrn Prof. Semon bei Amboina und Thursday Island gesammelten Ophiuroidea. Semon-Zool. Forschungsr., V, pp. 277-300, pls. XIV-XVIII.

1902 Japanische Euryaliden. Zool. Anz., XXV, pp. 320-326.

— 1911 Über japanische und andere Euryalae. Abhandl. math.-phys. Kl. K. Bayer. Akad. Wiss., Suppl.-Bd. II, Abhandl. 5, pp. 1-123, pls. I-IX.

KEHLER, R. 1897 Échinodermes recueillis par l'Investigator dans l'Océan Indien. Les Ophiures de mer profonde. Ann. Sci. Nat., Zool., Sér. 8, IV, pp. 277-372, pls. V-IX.

1899 An account of the deep-sea Ophiuroidea collected by the Roy. Indian Marine Survey Ship Investigator. Calcutta, pp. 1-76, pls. I-XIV.

1904 Ophiures de l'Expedition du Siboga. Pt. I. Ophiures de mer profonde. Leiden, pp. 1-176, pls. I-XXXVI. 
1922 Ophiurans of the Philippine Seas and adjacent waters. U. S. Nat. Mus., Bull. 100, V, pp. 1-486, pls. I-CIII.

- 1930 Ophiures recueillies par le Docteur Th. Mortensen dans les Mers d'Australie et dans l'Archipel Malais. Vidensk. Medd. fra Dansk naturh. Foren., LXXXIX, pp. 1-295, pls. I-XXII.

LürxeN Ch. 1869 Additamenta ad historiam Ophiuridarum. 3 Afdeling, pp. 24-109.

Lrman, Th. 1878 Ophiuridae and Astrophytidae of the "Challenger" Expedition. Part I. Bull. Mus. Comp. Zoöl., V, 7, pp. 65-168, pls. I-X.

- 1879 Ophiuridae and Astrophytidae of the "Challenger" Expedition. Part II. Bull. Mus. Comp. Zoöl., VI, 2. pp. 17-83, pls. XI-XVIII.

1882 Report on the Ophiuroidea dredged by the Challenger. The voyage of the Challenger, Zool., V, pp. 1-386, pls. I-XLVIII.

Matscmoro, H. 1915 A new classification of the Ophiuroidea: with descriptions of new genera and species. Proc. Acad. Nat. Sci., Philadelphia, pp. 43-92.

- 1917 A monograph of Japanese Ophiuroidea, arranged according to a new classification. Journ. Coll. Sci., Imp. Univ. Tokyo, XXXVIII, 2, pp. 1-408, pls. I-VII.

Mortensen, Th. 1933 Studies of Indo-Pacific Euryalids. Vidensk. Medd. fra Dansk naturh. Foren., XCVI, pp. 1-75, pls. I-V.

1934 Echinoderms of Hong Kong. Hong Kong Nat. Suppl., 3, pp. 1-14, pls. I-VIII.

Murakami, S. 1942 Ophiurans of Izu, Japan. Journ. Dept. Agric., Kyūsyū Imp. Univ., VII, 1, pp. 1-36. 